\title{
Flexural Behavior Of Flat And Folded Ferrocement Panels
}

Mohamad N. Mahmood

Assistant professor
Civil Engineering Department

Mosul University, Mosul, Iraq
Sura A. Majeed

Assistant lecturer

الخلاصة

تتضمن الدر استة الحالية وصف لنتائج فحص صفائح فيروسمنتية مستوية وصفائح مطوية و المسلحة بأعداد

مختلفة من المشبك السلكي. الهدف الرئيسي من هذه الفحوصنات هو دراسة تأثنر استخدام أعداد مختلفة من طبقات المشبك السلكي على مقاومة الثتي لهذه الصفائح تحت تأثثر حملين خطيين إلى حد الفشل, كل حمل يقع عند ثلث الفضاء

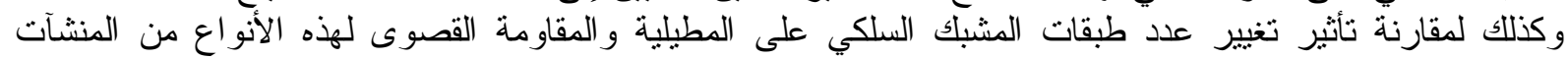

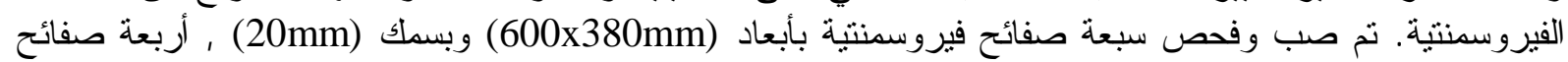
مستوية وثناثة صفائح مطوية. كذلك تم تحليل كلا النوعي باستخدام طريقة العناصر المحددة لبيان اجهادات الثني لهذه الصفائح تحت تأثير وزنها إضافة وإلى الحمل الحمل المسلط الذي سبب النشقق في الفحوصات العملية.

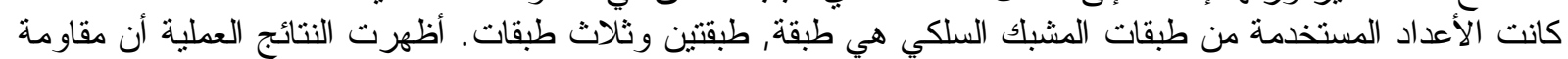
الانثناء للصفائح المطوية تزداد بمقدار (37\%) و (90\%) للصفائح ذات الطبقتين و الثلاث طبقات على التو الي, مقارنة مع الصفائح ذات الطبقة الواحدة, بينما تزداد مقاومة الثني للصفائح المستوية المسلحة مقارنة مع الصفة الصفيحة المستوية

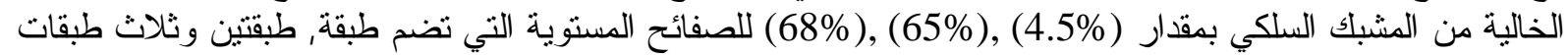

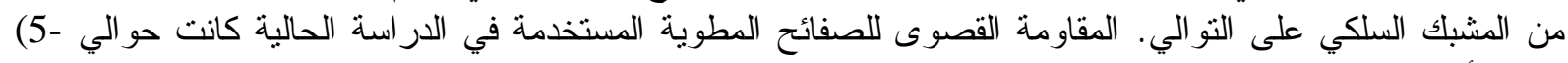
(3.5 أضعاف مقاومة نظيرتها من الصفائح المستوية و التي تمنلك نفس العدد من طبقات المشبك السلكي.
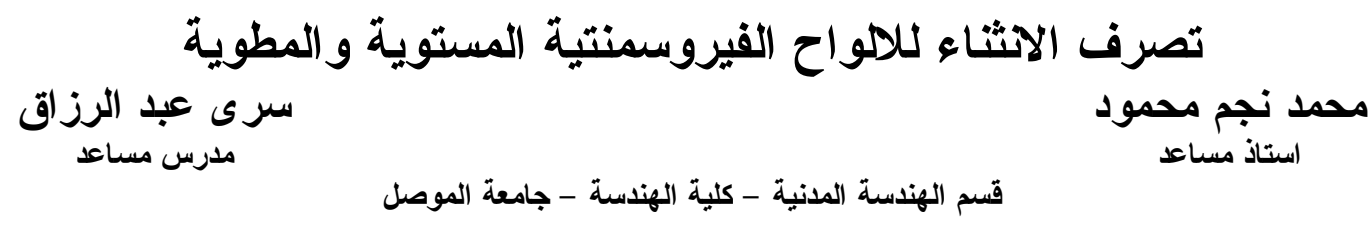

Abstract

The present paper describes the results of testing folded and flat ferrocement panels reinforced with different number of wire mesh layers. The main objective of these experimental tests is to study the effect of using different numbers of wire mesh layers on the flexural strength of folded and flat ferrocement panels and to compare the effect of varying the number of wire mesh layers on the ductility and the ultimate strength of these types of ferrocement structure. Seven ferrocement elements were constructed and tested each having $(600 \times 380 \mathrm{~mm})$ horizontal projection and $20 \mathrm{~mm}$ thick, consisting of four flat panels and three folded panels. The used number of wire mesh layers is one, two and three layers. The experimental results show that flexural strength of the folded panels increased by $37 \%$ and 90\% for panels having 2 and 3 wire mesh layers respectively, compared with that having single layer, while for flat panel the increase in flexural strength compared with panel of plan mortar is $4.5 \%, 65 \%$ and $68 \%$ for panels having 1,2 and 3 wire mesh layers respectively. The strength capacity of the folded panels, having the particular geometry used in the present study, is in the order of 3.5 to 5 times that of the corresponding flat panels having the same number of wire mesh layers. Both types are also analyzed using finite element method to check the flexural stresses in these panels under self weight and cracking load.

Keywords: Ferrocement, Flat Panel, Folded panel, Mortar, Wire Mesh. 


\section{$\begin{array}{llll}\text { Al-Rafidain Engineering } & \text { Vol.17 } & \text { No.4 } & \text { August } 2009\end{array}$}

\section{Introduction}

Ferrocement is one of the construction materials which may be able to fill the need for building light structures. Ferrocement composite consist of cement-sand mortar and single or multi-layers of steel wire mesh to produce elements of small thickness having high durability, resilience and when properly shaped it has high strength and rigidity. These thin elements can be shaped to produce structural members such as folded plates, flanged beams, wall panels...etc for use in the construction of cheap structures. Jain [1], presented a work on a ferrocement folded plate used for roofing industrial sheds. He describes the construction procedure of ferrocement roofing over reinforced concrete frame having six bays of $(14 \times 4.57 \mathrm{~m})$. Ferrocement folded plates roofing units were precast in $(7 \times 0.9 \mathrm{~m})$ effective size, hoisted and joined in their proper place. The study established the suitability of this system for industrial sheds. Desayi, et. al. [2], presented a study related to a residential house of size $(7.2 \times 3.3 \mathrm{~m})$ covered with precast ferrocement roofing elements having trapezoidal section. The elements were designed to carry the usual loads of house roof. Kaushik, et. al. [3], carried out an experimental and numerical investigation on the strength and flexural behavior of ferrocement box elements. The study proposed the use of modified modulus of elasticity of the composite when the load level is beyond the first cracking load. The numerical analysis was based on the finite strip method. Al-Sulaimani et. Al. [4] reported the test results of 19 ferrocement I and box-beams subjected to bending under two point loads. The studied parameters included the number of wire mesh layers; presence and absence of skeletal steel; beam length; effects of wire mesh in the webs. Mathematical model was proposed to predict the first crack stress and ultimate moment capacity of these types of structural elements. Kaushik and Gupta [5], carried out an experimental and analytical investigation on the strength and behavior of ferrocement rectangular and channel-shaped lintel elements tested under flexural load. Analytical approach for determining the cracking and ultimate flexural strength, deflections and crack widths have been proposed. Hago et.al. [6] presented the test results of six simply supported ferrocement roof slab panels, three flat slab and the other three having channel section. The studied parameters include the effects of percentage of wire mesh volume and the structural shape of the panels on the ultimate flexural strength, first cracking, crack spacing and load deflection behavior. The results indicate that the channel section is superior to that of flat slab in terms of service and ultimate behavior. Rao et. al. [7] studied the shear strength of 6 ferrocement panels having size 600x150mm with 25mm thick. Each panel was tested under various span to depth ratios from 1 to 6 . Based on the experimental result, a formula for predicting the shear strength of the ferrocement panel was proposed. A lot of works (in addition to the stated above) have been done to study the behavior of flat ferrocement panels but investigation of the behavior of folded ferrocement panels is very limited. The aim of the present work is to study the effect of varying the number of steel wire layers on the flexural behavior of folded ferrocement panels and to compare cracking, ultimate flexural strength and load deflection behavior with that of the flat panels. The number of wire mesh layers varied from zero to 3 in the flat panel while in the folded panel the wire mesh numbers is varied from 1 to 3 layers. Elastic analysis, using ANSYS finite element package was carried out to check the flexural stresses induced by the self weight and applied external load that causes initiation of the cracks in both types of the panel. 


\section{Experimental Program}

\section{Geometry of the specimens:}

The tested ferrocement elements consist of three folded panels and four flat panels. The dimensions of the folded and flat panels are shown in Fig. (1) which depicts that the horizontal projection of the folded panel is equal to $(380 \times 600 \mathrm{~mm})$ which is equal to the dimensions of the flat panel. The thickness of all the elements is equal to $20 \mathrm{~mm}$. The number and designation of the tested elements are given in Table (1). In handling the folded panel without wire mesh, it failed along the longitudinal folds after removing it from the mold so it has been excluded for the test results. The panels are constructed using the conventional ferrocement materials, which is composed of cement mortar and square wire meshes.

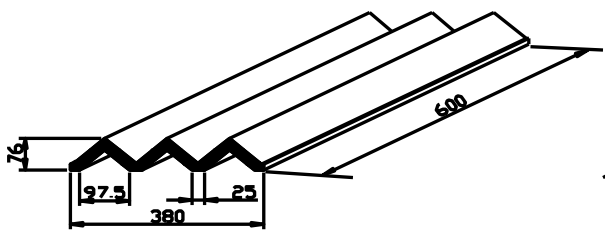

a- Folded nanel

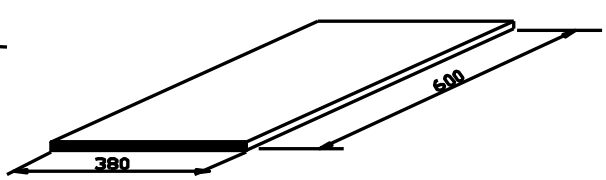

b- Flat nanel

Fig. (1) Dimensions of the folded and flat panels (dimensions are in $\mathrm{mm}$ ).

Table (1) Details of the tested panels.

\begin{tabular}{|c|c|c|}
\hline Panels number & panel type & Number of mesh layers \\
\hline A1 & \multirow{3}{*}{\} Folded panels } & 1 \\
\cline { 1 - 1 } A2 & \multirow{3}{*}{\} Flat panels } & 2 \\
\hline A3 & & 3 \\
\hline B1 & & 0 \\
\hline B2 & 1 \\
\hline B3 & 2 \\
\hline B4 & & 3 \\
\hline
\end{tabular}

Wire mesh:

The wire mesh used in the present work is mild steel galvanized welded wires of square grid having wire spacing equal to $12.5 \mathrm{~mm}$ with a wire diameter equal to $(0.65 \mathrm{~mm})$. Several wires were tested under tension and a typical stress-strain curve is given in Fig. (2). The average values of yield stress (fy), ultimate stress and modulus of elasticity are given in Table (2). The yield stress is determined corresponding to a $0.2 \%$ offset according to ASTM standard A370 [8].

Table (2) properties of the constituent materials.

\begin{tabular}{|l|c|}
\hline Mortar \\
\hline Cement : sand : water (by weight) & $1: 2: 0.45$ \\
Cube strength (7 days) & $22.5 \mathrm{MPa}$ \\
Cube strength (28 days) & $37.4 \mathrm{MPa}$ \\
Modulus of rupture (28 days) & $6.3 \mathrm{MPa}$ \\
\hline Wire mesh \\
\hline Grid size & $12.5 \times 12.5 \mathrm{~mm}$ \\
Diameter of wire & $0.65 \mathrm{~mm}$ \\
Yield stress (0.2\% offset) & $400 \mathrm{MPa}$ \\
Ultimate tensile strength & $500 \mathrm{MPa}$ \\
Modulus of elasticity & $63490 \mathrm{MPa}$ \\
\hline
\end{tabular}




\section{Al-Rafidain Engineering $\quad$ Vol.17 $\quad$ No.4 $\quad$ August 2009}

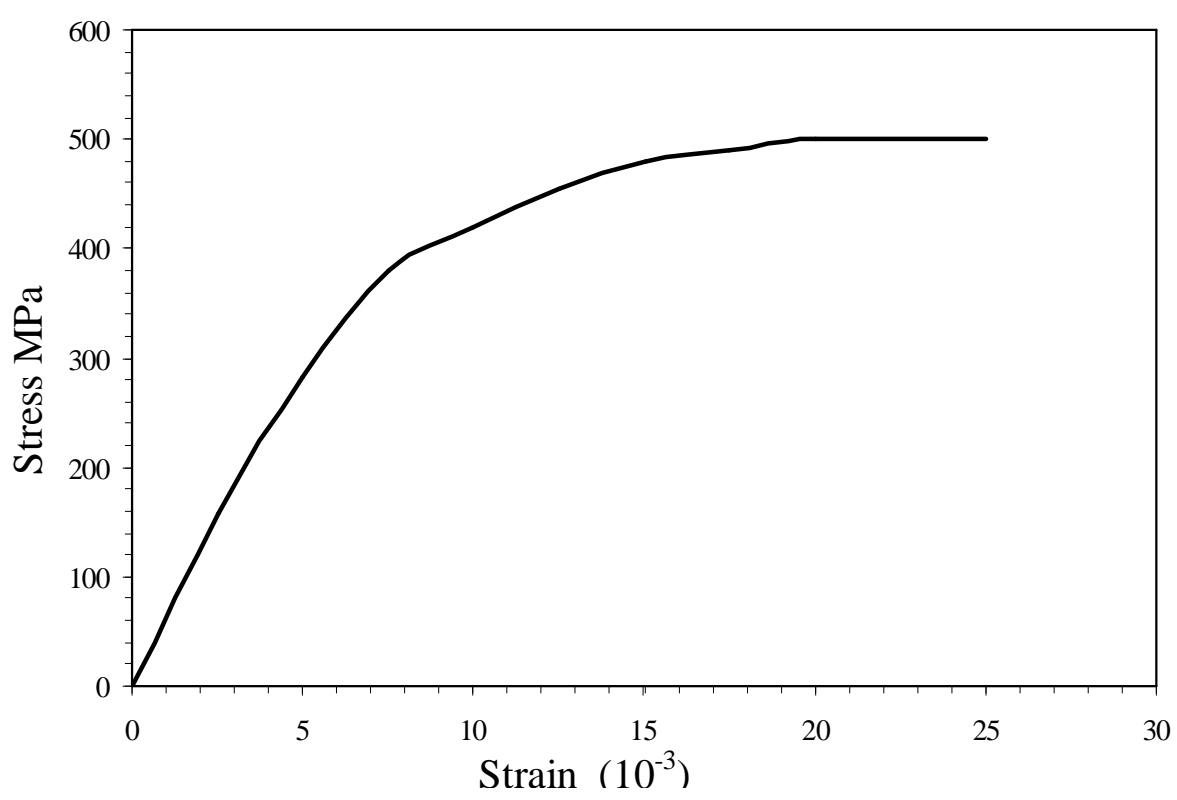

Fig. (2) Typical Stress-Strain curve for the wire.

\section{Cement Mortar:}

Ordinary Portland cement type I complying with the ASTM C 150 [9] is used in the mortar matrix. Normal weight river sand (from Kinhash, near Mosul city) with grading satisfying the ASTM C33 [10]. Tap clean and fresh water is used for the mortar mix and the used sandcement ratio and water cement ratio by weight were 2 and 0.45 , respectively; these are based on saturated surface dry sand and these ratios are kept constant for all the samples.

\section{Preparation and testing:}

A simple rectangular mold having $20 \mathrm{~mm}$ depth with $600 \times 380 \mathrm{~mm}$ dimensions is made for the flat panels; while a special mold for the folded panels is made to match the required geometry of the folded panel shown in Fig. (1). Each sample is molded after fixing the required wire mesh (or meshes) in its proper position through the thickness of the sample. Although it is not easy, particularly for the folded panels, special care and effort has been taken to maintain a uniform distribution of the wire meshes throughout the thickness of the panels, this was achieved by using small stone spacer. For the panels with single wire mesh, the mesh was placed at mid depth of the panels. The samples are removed from the mold 24 hours after casting and the elements are cured in water for 28 days at temperature ranges $20^{\circ}-25^{\circ} \mathrm{C}$. Six samples of standard cubes $(50 \times 50 \times 50 \mathrm{~mm})$ as per the ASTM C 109 [11] specification, are molded to determine the compressive strength of the mortar, three are tested at the age of 7 days and 3 at the age of 28 days. Also three standard prisms for testing the modulus of rupture of the mortar, as per the ASTM C348-02 [12] specification, are also prepared to measure the modulus of rupture of the used mortar. Properties of the mortar and wire mesh are summarized in Table (2). All the panels are tested under two line loads located at the third points of the $500 \mathrm{~mm}$ supported span. The setup of the tested folded and flat panels is shown in Fig. (3). Load is applied in small increments and simultaneously the deflection at the center of the panel was recorded during the loading process up to failure. The deflection at midspan is measured by a dial gage having accuracy equal to $0.01 \mathrm{~mm}$. Cracking was carefully checked throughout the loading process and the corresponding cracking load is also noted. 

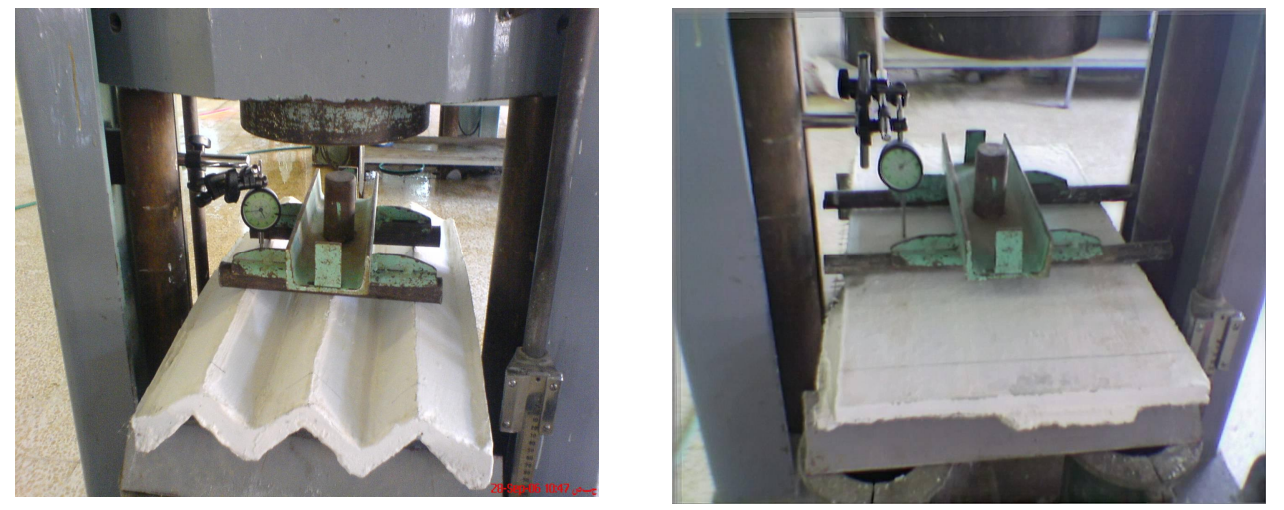

Fig. (3) Setup of the tested folded and flat panels.

\section{Results and Discussion}

The parameters that had been investigated in this study are the effect of the geometry of the panels and number of wire mesh layers on the cracking load and ultimate flexural strength and to plot the load deflection curve for each panel. The test results of the samples at the age of (28 days) from the day of casting are presented in Table (3) in which the cracking, ultimate load and flexural strength for the tested ferrocement panels are summarized. The table shows the gain in the ultimate strengths with the increase in the number of wire mesh layers for the two types of the panel. It can be noticed that the cracking load is almost constant for the folded panels and it was not affected by the number of the wire mesh layers. The load deflection curves for the folded panels are shown in Fig. (4) and as can be seen in this figure and Table (3) that increasing the number of wire mesh layers from 1 to 3 causes to increase the ultimate load from $(4750 \mathrm{~N})$ to $(9000 \mathrm{~N})$. For the folded panel with one layer of wire mesh, once cracking started it did not sustain any further load and it failed after only $(200 \mathrm{~N})$ increment of load. The percentage increase in the load capacity of panels A2 and A3 with respect to panel A1 is in the order of $37 \%$ and $90 \%$ respectively. Figure (4) also depicts that, on the contrary to the flat panels, the initial stiffness of the folded panel is not affected by the number of wire mesh. Test results, in terms of load deflection curves, for the flat panels are presented in Fig. (5) and the cracking loads and ultimate strength for the same are given in Table (3). It can be noticed that cracking load varies from 775 to $985 \mathrm{~N}$. It is worth mentioning that the single wire mesh is located at the mid depth of the panel, while in the case of using two and three layers they are distributed throughout the thickness with a cover of $(3 \mathrm{~mm})$ at the top and bottom faces. This explains the ineffectiveness of using one layer in the flat panel where the failure load increased from $1100 \mathrm{~N}$ for B1(plain mortar) to 1150 for B2 (one layer mesh). The single layer did not contribute in increasing the strength of the panel since it is located at mid depth (close to the neutral axis of the section) and the stress in these wires is very small even in the post cracking stages, nevertheless it significantly increased the ductility of the panel as shown in Fig. (5) in comparison with the plain mortar panel (B1). Figure (5) also shows that by using two layers in panel (B3) and three layers in panel (B4) the behavior of the panels is significantly improved in terms of initial stiffness, ductility and energy absorption (area under the load deflection curve). The minor difference in the ultimate load of panel (B3) and (B4) is due to the fact that the third wire mesh layer in (B4) is located at mid depth of the panel so it did not increase the flexural strength of this panel. Nevertheless the stiffness and capacity of energy absorption for panel (B4) is larger than that of panel B3. For panel (B1) once cracking started at the load of (985), it suddenly failed after load increment of only $(115 \mathrm{~N})$. Panels (B3) and (B4) show higher ultimate strength by $65 \%$ and $68 \%$ respectively compared with panel (B1). Table (3) also shows that the ratio of the flexural 


\section{Al-Rafidain Engineering $\quad$ Vol.17 No.4 $\quad$ August 2009}

strength of the folded panel, having specified number of wire mesh layers, to the corresponding flat panel is in the range of (3.5 to 5) times. Crack patterns at the top face of the folded and flat panels are shown in Figs. (6) and (7) respectively. It is worth to mention that at failure load, for both types of panel, the cracks at failure load extended to the top face of the panel as it is clear from Figs. (6) and (7).

Table (3) Cracking load and ultimate flexural strength of the tested panels.

\begin{tabular}{|c|c|c|c|}
\hline $\begin{array}{c}\text { Panel } \\
\text { number }\end{array}$ & $\begin{array}{c}\text { Cracking Load } \\
(\mathrm{N})\end{array}$ & $\begin{array}{c}\text { Ultimate Load } \\
(\mathrm{N})\end{array}$ & $\begin{array}{c}\text { Flexural strength } \\
(\mathrm{N} . \mathrm{mm} / \mathrm{mm})\end{array}$ \\
\hline A1 & 4550 & 4750 & 1042.0 \\
\hline A2 & 4450 & 6500 & 1425.0 \\
\hline A3 & 4450 & 9000 & 1975.0 \\
\hline B1 & 985 & 1100 & 241.0 \\
\hline B2 & 775 & 1150 & 252.0 \\
\hline B3 & 835 & 1820 & 400.0 \\
\hline B4 & 945 & 1850 & 406.0 \\
\hline
\end{tabular}

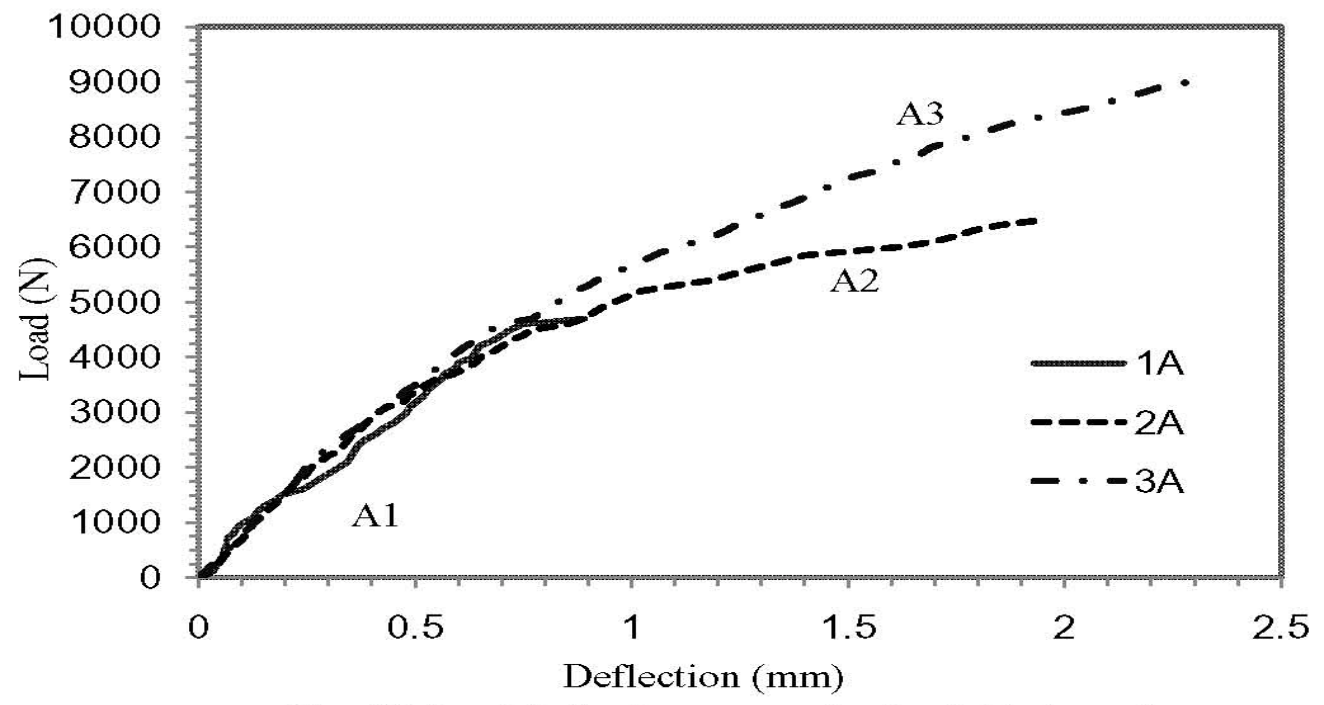

Fig. (4) Load deflection curves for the folded panels.

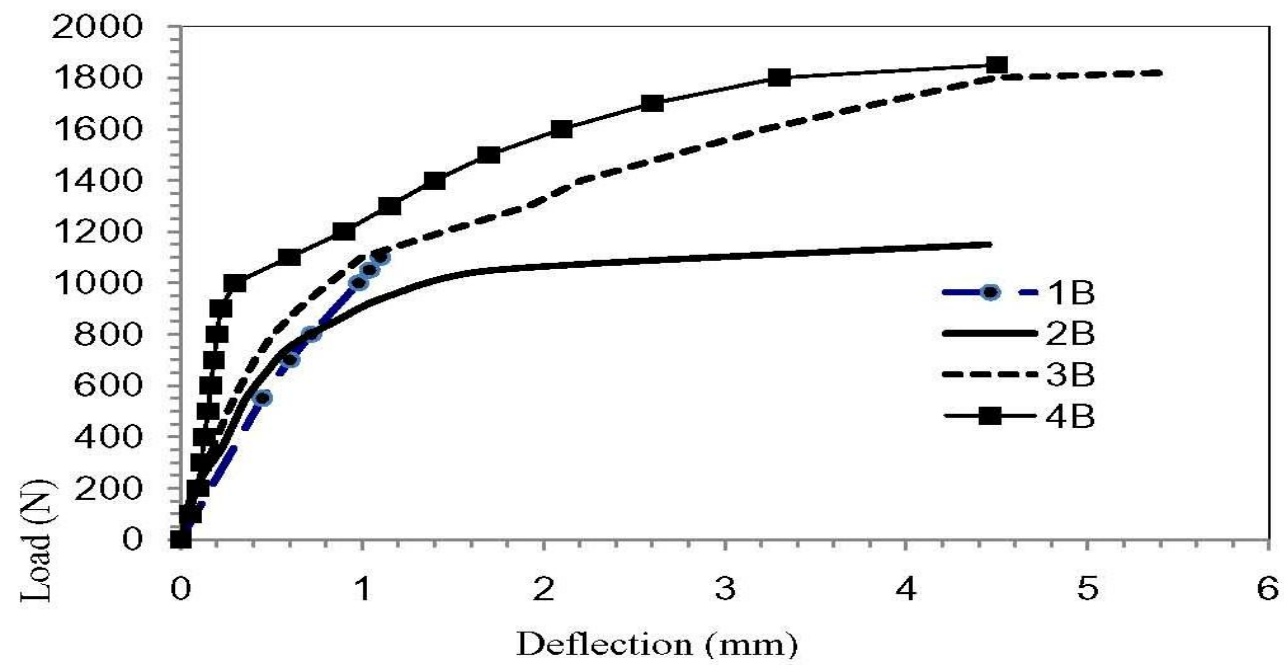

Fig. (5) Load deflection curves for the flat panels. 
Mahmood: Flexural Behavior Of Flat And Folded Ferrocement Panels
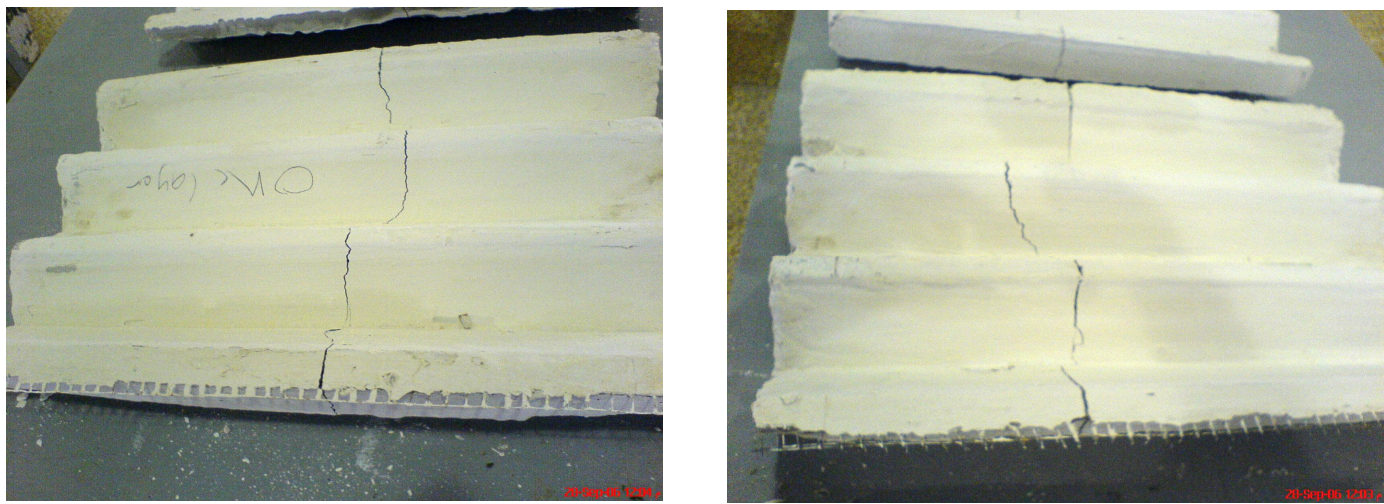

A1

A2

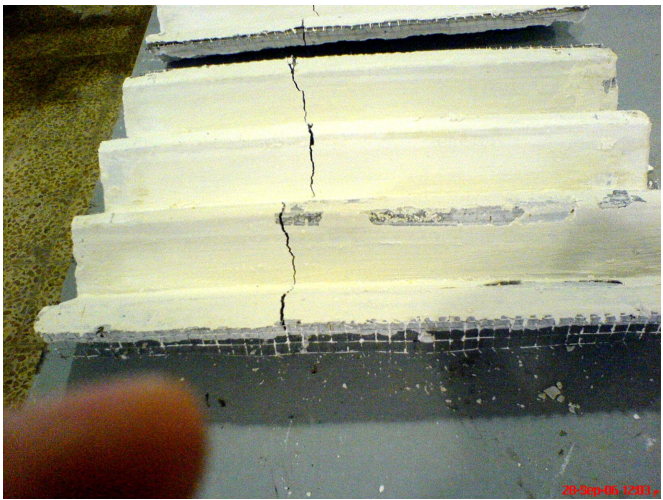

A3

Fig. (6) Crack pattern at the top face of the folded panels.

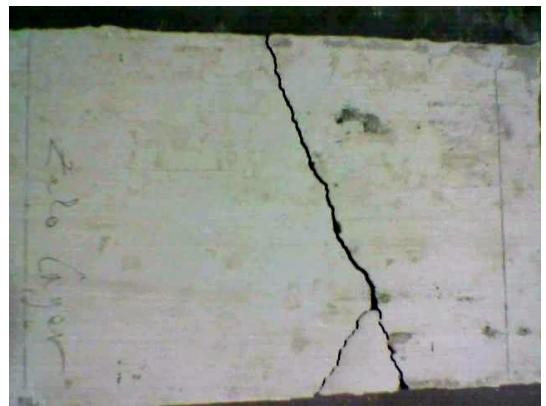

B1

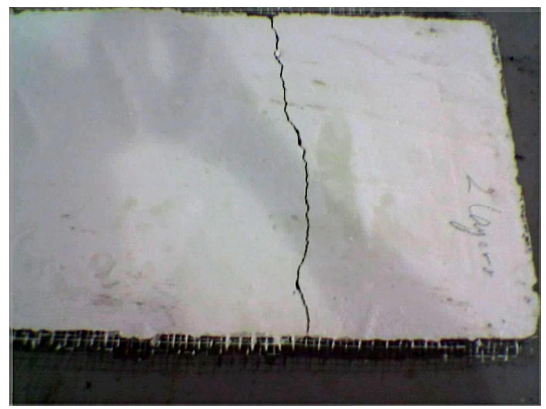

B3

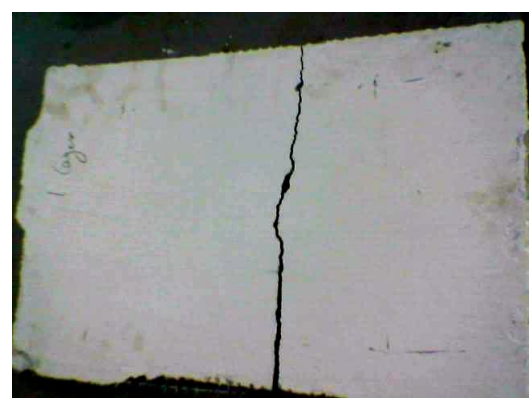

B2

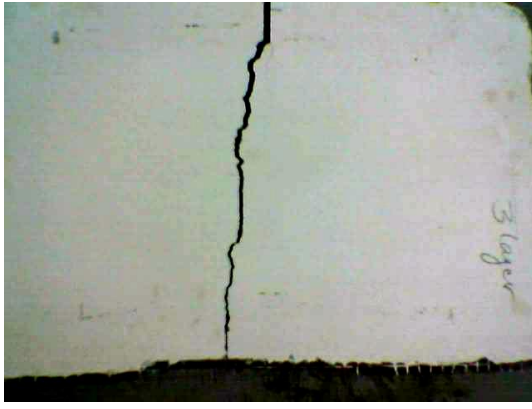

B4

Fig. (7) Crack pattern at the top face of the flat panels. 


\section{$\begin{array}{llll}\text { Al-Rafidain Engineering } & \text { Vol.17 No.4 } & \text { August } 2009\end{array}$}

\section{Finite Element Analysis}

To check the stresses at which cracking has been initiated for both types of the tested panels, an elastic finite element analysis was carried using ANSYS- Release-10.0 package [13]. Making advantage of the symmetry in geometry and loading, only quarter of each panel type was analyzed using proper boundary conditions. Solid 45 brick element having 8 nodes with the extra displacement to modify the behavior of the element in pure flexure [14] is adopted to model the panels. For the flat panel, 950 elements $(19 \times 25 \times 2)$ (two elements through the depth) were used, while 3700 elements were used to model the folded panel (with 4 elements through the thickness). For the flat panel a quarter of the average cracking load of $880 \mathrm{~N}$, that is $220 \mathrm{~N}$, is applied since quarter of the panel is used in the finite element model. This load is distributed amongst the 20 nodes located at the third span in addition to the gravitational load (self weight of the panel). The predicted variation of the flexural stresses at the bottom face is shown in Fig. (8) which indicates that flexural stresses are constant within the middle third of the span, and this is because the stresses due to self weight is only marginal compared with that induced by the external load. The figure also depicts that the maximum tensile stress at the bottom face of the panel under this loading is only (3.26MPa) which is almost half the flexural strength of the prism of the same mortar $(6.3 \mathrm{MPa})$ as given in Table (2). The maximum tensile stress due to the self weight is only $(0.22 \mathrm{MPa})$, determined by analyzing the panel under gravitational load only, while that due to the external applied load is $(3.04 \mathrm{MPa})$ determined by analyzing quarter of the panel under quarter of the average cracking external load $(220 \mathrm{~N})$. The difference between the modulus of rupture and cracking stress may be attributed to the effects of the size and the difference in the geometry of the tested flat panel compared with the prism used to determine the modulus of rupture and also the effect of good compaction of the prism compared with the procedure of casting the panels without compaction. The experimental results in reference [7] have also shown that the cracking flexural stresses in the panel elements with plain mortar tested under 4 points load, are almost half the tensile strength of the mortar particularly when the shear span to depth ratio is more than 3. For the folded panels a quarter of the average cracking load $(4500 \mathrm{~N})$, that is $(1125 \mathrm{~N})$, is applied at the highest two nodes, $(375 \mathrm{~N})$ at the node located at the centerline of the panel and $(750 \mathrm{~N})$ at the top node of the first fold and both are located at the third span of the panel. The gravitational (self weight) is also included in the analysis. The predicted flexural stresses at the bottom of the panel is shown in Fig. (9) which depicts that the maximum tensile stress is equal to $(4.501 \mathrm{MPa})$ which is about two thirds the modulus of rupture determined from the flexural test of the mortar prism. The maximum tensile stress due to the self weight of the panel is equal to $(0.083 \mathrm{MPa})$, while that due to the applied external load is equal to $(4.421 \mathrm{MPa})$. It can be stated that for the flat panel the flexural stress due to the self weight is about $6.75 \%$ of the cracking stress; while for the folded panel it is only $1.8 \%$ of the cracking stress. It is worth to mention that the total weight of the $500 \mathrm{~mm}$ span of the flat panel is $82 \mathrm{~N}$; while that of the folded panel is $116.7 \mathrm{~N}$ that is $42 \%$ more than the flat panel; nevertheless the developed maximum flexural stress in the folded panel due to the self weight is about one third of that of the flat panel and the average ultimate capacity of the folded panel is about 4 times that of the flat panel having same number of layers of wire mesh. This indicates the superiority of the folded panel in terms of the ultimate carrying capacity and stress distribution. 


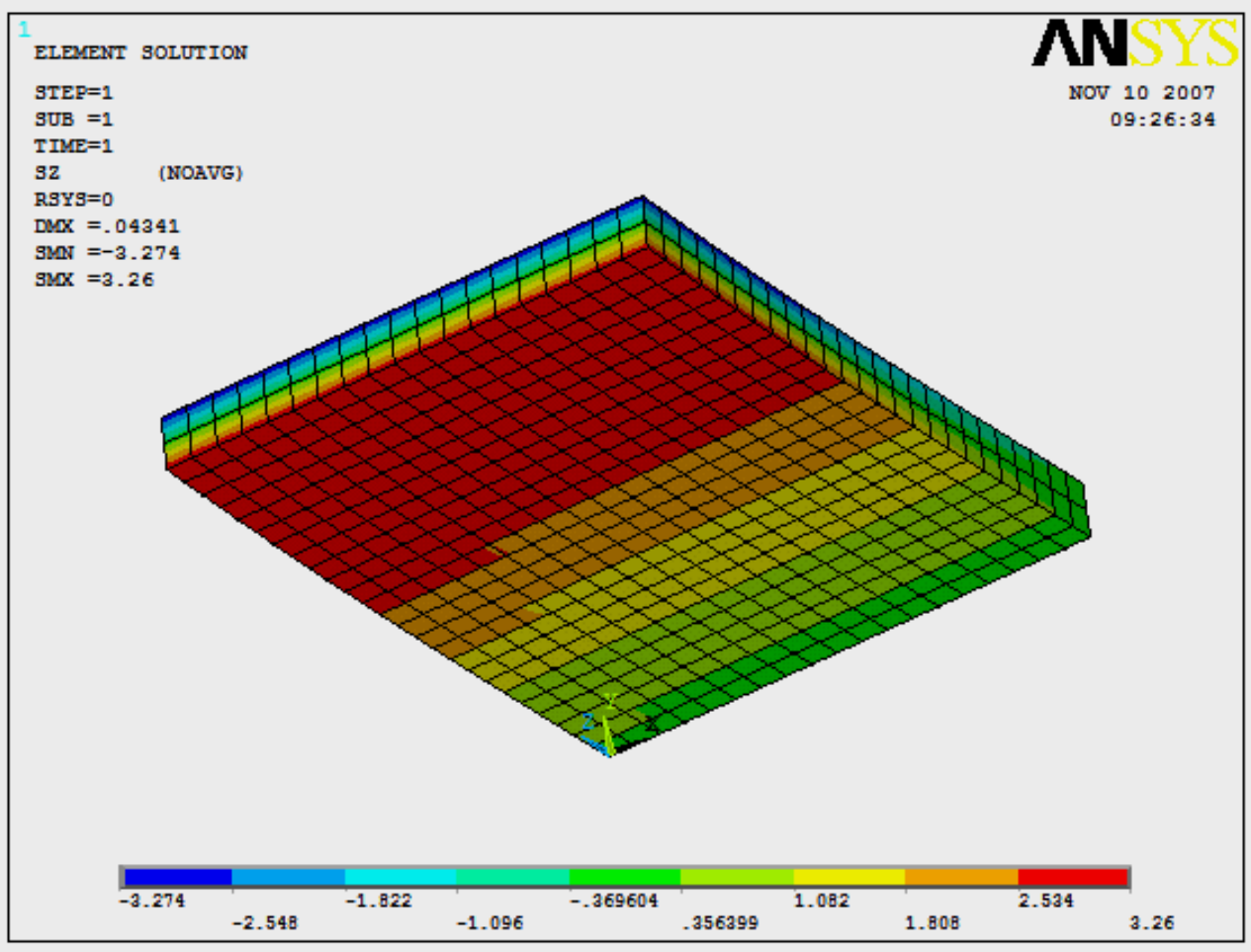

Fig. (8) Flexural stresses in the flat panel due to cracking and gravity loads.

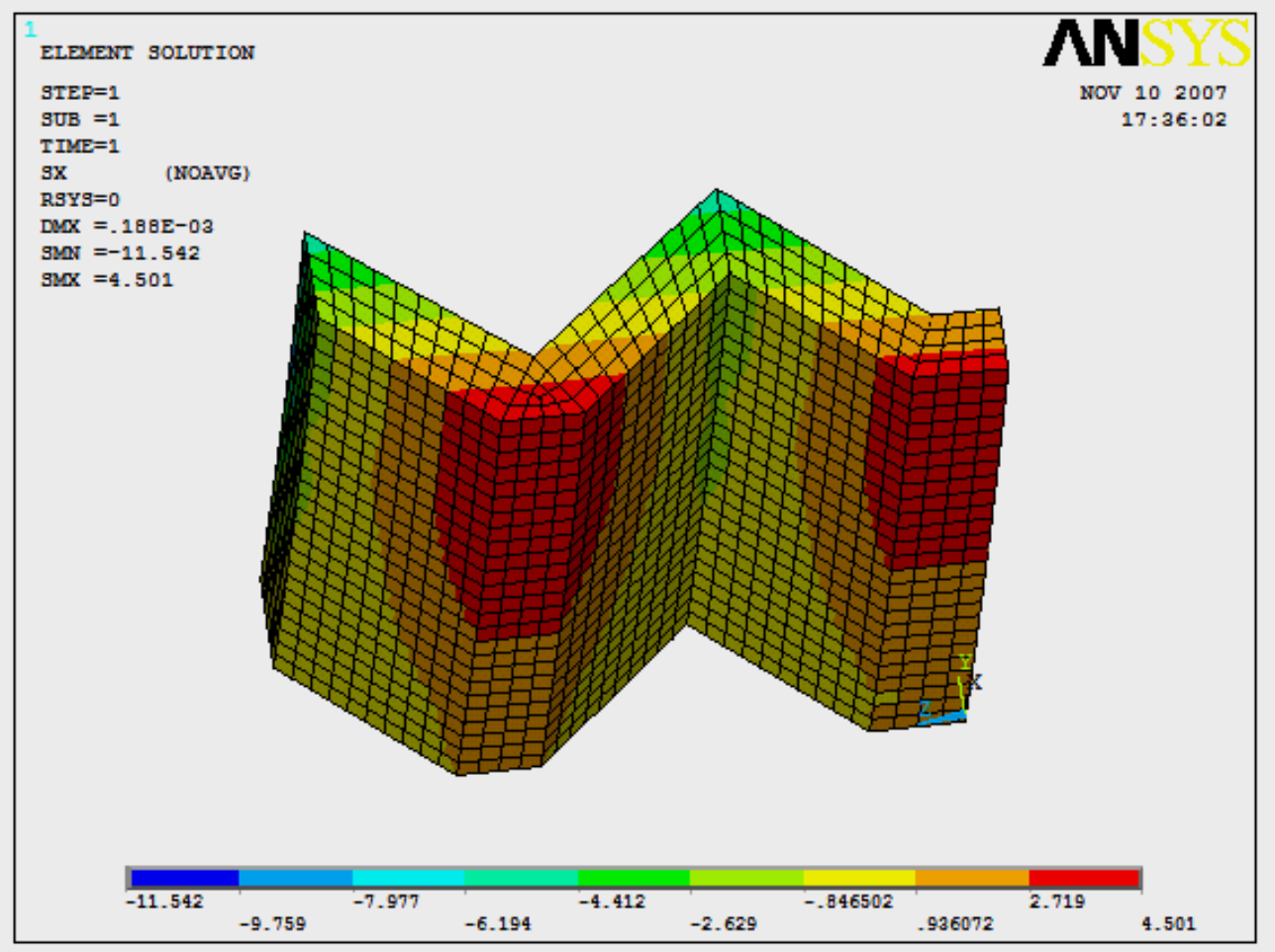

Fig. (9) Flexural stresses in the folded panel due to cracking and gravity loads. 


\section{$\begin{array}{llll}\text { Al-Rafidain Engineering } & \text { Vol.17 } & \text { No.4 } & \text { August } 2009\end{array}$}

\section{Concluding Remarks}

Based upon the experimental test results of the folded and flat panels the following can be stated:

- The cracking load was not significantly affected by the number of the wire mesh particularly for the folded panels.

- The flexural strength of the folded panel increased by 37 and 90 percent for panels having 2 and 3 wire mesh layers compared with that of single layer; while for the flat panel the percentage increase in the flexural strength using 2 and 3 layers is $65 \%$ and $68 \%$ compared with that of plain mortar panel. The gain in the flexural strength of the flat panel with single layer, located at mid depth of the section, compared with that of plain mortar is only marginal. But using single layer helps in increasing the ductility of the flat panel.

a The experimental and numerical results show the superiority of the folded to the flat panel in terms of ultimate strength and initiation of cracking.

- Finally increasing the number of layers of wire mesh from 1 to 3 layers significantly increases the ductility and capability to absorb energy of both types of the panel.

\section{References}

1- Jain, A.K., "Ferrocement Folded Plate Roofing Industrial Sheds", India Concrete Journal, Vol. 55, No. 6, June 1981, pp. 146-149.

2- Desayi, P., Viswanatha, C.S. and Hubli, G.K., "Ferrocement Precast Elements for Roofing of Low-Cost Housing", Journal of Ferrocement, Vol. 13, No. 1, January 1983, pp. 19-39.

3- Kaushik, S.K., Gupta, V.K. and Sehgal, V.K., "Performance Evaluation of Ferrocement Box Girder Elements for Roofs and Floors", Journal of Ferrocement, Vol. 18, No. 4, October 1988, pp. 413-420.

4- Al-Sulaimani, G.J., Ahmad, S.F. and Basunbul, I.A., "Study of the Flexural Strength of Ferrocement 'Flanged' Beams", The Arabian Journal for Science and Engineering, Vol. 14, No. 1, January 1989, pp. 33-46.

5- Kaushik, S.K. and Gupta, V.K., " Performance Appraisal of Ferrocement North Light Folded Plates", Fiber Reinforced Cement and Concrete, Proceedings of the Forth International Symposium Held by RILEM, and Organized by the Department of Mechanical and Process Engineering, University of Sheffield, U.K., July 1992.

6- Hago, A.W., Al-Jabri, K.S., Alnuaimi, A.S., Al-Mogbali, H., Al-Kbaisy, M.A., "Ultimate and Service Behavior of Ferrocement Roof Slab Panels", Construction and Building Materials 19 (2005) pp. 31-37.

7- Rao, T.C., Rao, T.D. and Rao, N.V., "An Appraisal of the Shear Resistance of Ferrocement Elements", Asian Journal of Civil Engineering (Building and Housing) Vol. 7, No. 6 (2006) pp 591-602.

8- ASTM A370-02, "Standard Test Methods and Definitions for Mechanical Testing of Steel Products", American Society for Testing and materials, west Conshohocken, Pennsylvania 2002.

9- ASTM C 150, "Standard Specification for Portland Cement", American Society for Testing and materials, west Conshohocken, Pennsylvania 1989.

10- ASTM C33-99, "Standard Specification for Concrete Aggregates", American Society for Testing and materials, west Conshohocken, Pennsylvania 1999. 
11- ASTM C 109/C 109M-02 "Standard Test Method for Compressive Strength of Hydraulic Cement Mortars Using 50mm Cube Specimens", American Society for Testing and materials, west Conshohocken, Pennsylvania 2002.

12- ASTM C 348 - 02 " Standard Test Method for Flexural Strength of Hydraulic-Cement Mortars", American Society for Testing and materials.

13- ANSYS, Release 10.0, copy right 2005, SAS IP, Inc.

14- Krishnamoorthy, C. S. "Finite Element Analysis, Theory and Programming", Tata McGraw-Hill Publishing Company Limited, New Delhi, 1988. 